\title{
PERAN KELENGKAPAN IMUNISASI DASAR DALAM TUMBUH KEMBANG ANAK USIA 1 - 3 TAHUN DI POSYANDU DEWI SAWITRI KARTASURA
}

\author{
Ratna Indriati ${ }^{1}$, Anita Silvia Anggraini ${ }^{2}$
}

\begin{abstract}
Background: Child development is a very important part. The percentage of underweight under five years of age in Indonesia at 2017 was $17.8 \%$. Children's vulnerability to the disease can affect children's growth can be reduced either by giving immunizations. Children who get complete immunization will have strong immunity and becoming healthy children, where the conditions favor the optimal development of the child. At Posyandu Dewi Sawitri there are children immunized incomplete and growth are not in accordance with his age.

Purpose and benefit: To determine the role of complete basic immunization in child development. The benefits of the research are highlighted the importance of a complete basic immunization in children as one of the efforts to promote growth and development of children.

The subject of study: 56 children aged 1-3 years in Posyandu Dewi Sawitri Kartasura.

Method Research of analytical observation, correlation design with cross sectional method. Sampling is purposive sampling. The data obtained were analyzed with Chi Square test with $p=0.05$.

The Result of Research: Have shown that children with a complete basic immunization of 40 children $(71.4 \%)$, did not complete 16 children (28.6\%). Children with optimal growth of 37 children $(66.1 \%)$, is not optimal 19 children (33.9\%). Children with developmental corresponding 46 children (82.1\%), do not fit in 10 children (17.9\%). The results of the analysis of complete basic immunization role in the growth of children using Chi Square test was obtained $p=0.026$ ( $p<0.05$ ), which means Ha accepted, and role in child development obtained $p=0.001(p<0.05)$, which means Ha accepted.

Conclusion: Complete basic immunization role in growth and development of the child.
\end{abstract}

Keywords: Completeness of immunization, child development, child growth

\section{PENDAHULUAN}

Anak merupakan generasi penerus dan investasi bagi masa depan bangsa. Pertumbuhan dan perkembangan anak di bawah lima tahun merupakan bagian yang sangat penting (Dinkes, 2013). Pada usia ini anak berada pada fase pertumbuhan dan perkembangan yang sangat pesat dan berada pada periode kritis. Hambatan dalam pertumbuhan dan perkembangan pada periode ini akan berpengaruh pada pertumbuhan dan perkembangan anak sampai usia dewasa, sedangkan pada usia ini anak rawan mengalami berbagai penyakit. Penyakit selama masa pertumbuhan dan perkembangan dapat mencegah anak mencapai potensi fisik dan perkembangan yang optimal.

Percepatan tumbuh kembang anak dipengaruhi oleh kesehatan anak, sebaliknya apabila anak memiliki status kesehatan kurang maka anak akan mengalami perlambatan tumbuh kembang. Anak yang mengalami penyakit kronis akan menyebabkan berkurangnya kemampuan anak untuk berkembang (Suryani dan Badi'ah, 2017). Hal tersebut menunjukkan bahwa kerentanan anak terhadap penyakit dapat mempengaruhi tumbuh kembang anak. Seperti hasil penelitian yang dilakukan oleh Kusminarti (2009), mengenai faktor 
- faktor yang berhubungan dengan pertumbuhan balita menunjukkan bahwa penyakit infeksi berhubungan secara signifikan dengan pertumbuhan balita $(p=0.003)$. Demikian pula penelitian yang dilakukan oleh Dewi dan Adhi (2016) menunjukkan bahwa faktor yang dominan yang mempengaruhi kejadian stunting adalah konsumsi seng $(O R=9.94)$ dan riwayat penyakit infeksi $(O R=5.41)$.

Kerentanan anak terhadap penyakit bisa dikurangi salah satunya dengan memberikan imunisasi. Dengan imunisasi diharapkan anak dapat terhindar dari penyakit yang menyebabkan cacat atau kematian (Soetjiningsih dan Ranuh, 2014). Imunisasi merupakan salah satu cara pencegahan penyakit menular khususnya Penyakit yang Dapat Dicegah dengan Imunisasi (PD3I). Menurut Permenkes RI No. 42 tahun 2013 tentang penyelenggaraan imunisasi, menyebutkan imunisasi adalah suatu upaya untuk menimbulkan/meningkatkan

kekebalan seseorang secara aktif terhadap suatu penyakit, sehingga bila suatu saat terpajan dengan penyakit tersebut tidak akan sakit atau hanya mengalami sakit ringan (Suryani dan Badi'ah, 2017). Sehingga anak yang mendapatkan imunisasi lengkap akan memiliki kekebalan tubuh yang kuat dan akan menjadi anak yang sehat, dimana kondisi anak yang sehat akan mendukung pertumbuhan dan perkembangan anak yang optimal.

Tumbuh kembang merupakan manifestasi yang kompleks dari perubahan morfologi, biokimia, dan fisiologi yang terjadi sejak konsepsi sampai maturitas/dewasa. Pada usia ini anak mengalami pertumbuhan fisik dan perkembangan motorik yang berlangsung cepat, mempunyai kemampuan belajar dan mengingat, kesadaran diri (selfawareness) mulai berkembang, bahasa berkembang pesat, rasa tertarik terhadap anak lain meningkat (Soetjiningsih dan Ranuh, 2014). Sedangkan menurut Sulistyawati (2014), perkembangan adalah bertambahnya kemampuan dalam struktur dan fungsi tubuh yang lebih kompleks dalam pola yang teratur sebagai hasil dari proses pematangan.

Berdasarkan penelitian yang dilakukan oleh Hikmah, Riyantini dan Wahyuni (2016), yang berjudul hubungan kelengkapan imunisasi dasar dengan tumbuh kembang toddler di Posyandu Bunga Padi Kota Tangerang diperoleh data sebanyak $85 \%$ balita diberikan imunisasi dan sebanyak $15 \%$ balita tidak diberikan imunisasi. Dari hasil penelitian disimpulkan bahwa ada hubungan antara kelengkapan imunisasi dasar dengan pertumbuhan anak $(p=0.000)$ dan ada hubungan antara kelengkapan imunisasi dasar dengan perkembangan anak $(p=0.000)$. Kerentanan terhadap penyakit dapat dikurangi dengan memberikan imunisasi secara rutin dengan begitu akan memberikan efek positif pada anak terutama pada pertumbuhan dan perkembangannya. Demikian juga penelitian yang dilakukan oleh Kaunang, Rompas dan Bataha (2016), menunjukkan terdapat hubungan pemberian imunisasi dasar dengan pertumbuhan dan perkembangan bayi ( $p$ value $=$ 0.000).

Program imunisasi meliputi imunisasi dasar dan imunisasi tambahan. Untuk imunisasi dasar merupakan imunisasi rutin dan wajib dilaksanakan. Macam-macam imunisasi dasar adalah imunisasi BCG, DPT I-III, Polio I-IV, Campak dan Hepatitis B (Ridha, 2014). Imunisasi tersebut diberikan pada anak untuk memberikan kekebalan pada anak terhadap penyakit TBC, Difteri, Pertusis, Tetanus, Poliomyelitis dan Hepatitis. 
Berdasarkan hasil pemantauan status gizi di Indonesia tahun 2017, persentase berat badan kurang pada kelompok usia balita (bawah lima tahun) adalah $17.8 \%$ dan kelompok usia baduta (bawah dua tahun) adalah 14.8\% (Kemenkes RI, 2018).

Hasil wawancara yang dilakukan dengan bidan desa dan kader Posyandu Dewi Sawitri Pucangan Kartasura, masih ada anak yang imunisasi dasarnya tidak lengkap dan terdapat anak yang mengalami gangguan perkembangan serta anak yang berat badannya tidak sesuai dengan usianya. Selama ini di wilayah Pucangan belum pernah dilakukan penelitian mengenai peran kelengkapan imunisasi dasar dalam tumbuh kembang anak.

Berdasarkan uraian di atas, penulis tertarik untuk melakukan penelitian tentang peran kelengkapan imunisasi dasar dalam tumbuh kembang anak usia 1-3 tahun di Posyandu Dewi Sawitri RW 07 Pucangan Kartasura.

Perbedaan penelitian ini dari penelitian sebelumnya adalah lokasi penelitian dimana penelitian ini dilakukan di Posyandu Dewi Sawitri. Peneliti memilih lokasi ini karena jumlah anak usia 1-3 tahun di posyandu ini cukup besar yaitu 66 anak dan peneliti menentukan responden pada usia 1-3 tahun karena pada usia tersebut sesuai jadwal imunisasi dasar maka anak sudah melampaui seluruh imunisasi yang diwajibkan sehingga kelengkapan imunisasi dasar pada anak bisa diukur.

\section{TUJUAN PENELITIAN}

Tujuan umum penelitian untuk mengetahui peran kelengkapan imunisasi dasar dalam pertumbuhan dan perkembangan anak usia 1-3 tahun, dan tujuan khusus untuk mengidentifikasi kelengkapan imunisasi dasar anak, mengidentifikasi pertumbuhan anak dan mengidentifikasi perkembangan anak usia 1-3 tahun.

\section{METODE PENELITIAN}

Penelitian ini merupakan penelitian analitik observasional dengan desain korelasi untuk mengkaji hubungan kelengkapan imunisasi dasar sebagai variabel bebas dengan pertumbuhan dan perkembangan anak sebagai variabel terikat. Pengumpulan data dengan cara observasi dan data yang sudah terkumpul dianalisa menggunakan Uji Chi-Square dengan program SPSS versi 18.0.

\section{POPULASI, SAMPEL DAN TEKNIK SAMPLING}

Subyek penelitian adalah anak usia 1-3 tahun di Posyandu Dewi Sawitri Kartasura yang berjumlah 56 responden. Dalam penelitian ini peneliti menggunakan teknik purposive sampling dengan kriteria inklusi anak laki-laki dan perempuan yang tercatat sebagai anggota Posyandu, anak memiliki KMS (Kartu Menuju Sehat), dan anak tidak ada riwayat penyakit kronis maupun retardasi mental.

\section{HASIL PENELITIAN}

Berdasarkan penelitian yang telah dilakukan didapatkan karakteristik responden berdasarkan umur dan jenis kelamin anak beserta hasil penelitian mengenai peran kelengkapan imunisasi dasar dalam tumbuh kembang anak, yaitu sebagai berikut :

Tabel 1.

Distribusi Frekuensi Karakteristik Responden

\begin{tabular}{cccc}
\hline $\begin{array}{c}\text { Karak- } \\
\text { teristik }\end{array}$ & Kategori & $\mathrm{f}$ & $\%$ \\
\hline $\begin{array}{c}\text { Umur anak } \\
\text { (bln) }\end{array}$ & $12-24$ & 26 & 46.4 \\
& $25-36$ & 30 & 53.6 \\
Jenis & Laki-laki & 28 & 50 \\
kelamin & Perempuan & 28 & 50 \\
\hline
\end{tabular}


Dari data di atas diperoleh informasi bahwa jumlah responden pada kelompok umur 25-36 bulan lebih besar yaitu 30 anak (53.6\%) daripada kelompok umur 12-24 bulan yaitu 26 anak (46.4\%), dan jumlah responden dengan jenis kelamin laki-laki sama dengan jenis kelamin perempuan yaitu 28 anak.

Tabel 2.

Distribusi Frekuensi Imunisasi, Pertumbuhan dan Perkembangan

\begin{tabular}{cccc}
\hline Variabel & Kategori & $f$ & $\%$ \\
\hline Imuni- & Lengkap & 40 & 71.4 \\
sasi & Tdk lengkap & 16 & 28.6 \\
Pertum- & Optimal & 37 & 66.1 \\
buhan & Tdk optimal & 19 & 33.9 \\
Perkem- & Sesuai & 46 & 82.1 \\
bangan & Tdk sesuai & 10 & 17.9 \\
\hline
\end{tabular}

Dari Tabel 2 di atas dapat dicermati bahwa jumlah responden yang mendapatkan imunisasi dasar lengkap lebih banyak yaitu 40 anak $(71.4 \%)$ dan yang mendapatkan imunisasi dasar tidak lengkap adalah 16 anak (28.6\%). Anak yang memiliki pertumbuhan optimal lebih banyak yaitu 37 anak (66.1\%) dan pertumbuhan tidak optimal sebanyak 19 anak (33.9\%). Anak yang memiliki perkembangan sesuai lebih banyak yaitu 46 anak (82.1\%) dan tidak sesuai sebanyak 10 anak $(17.9 \%)$.

Tabel 3.

Tabulasi Silang Kelengkapan Imunisasi dan Pertumbuhan

\begin{tabular}{cccc}
\hline \multirow{2}{*}{ Imunisasi } & \multicolumn{3}{c}{ Pertumbuhan } \\
\cline { 2 - 4 } & Optimal & $\begin{array}{c}\text { Tidak } \\
\text { Optimal }\end{array}$ & Total \\
\hline Lengkap & 30 & 10 & 40 \\
& $(75.0)$ & $(25.0)$ & $(100)$ \\
Tdk lengkap & 7 & 9 & 16 \\
& $(43.7)$ & $(56.3)$ & $(100)$ \\
\hline Total & 37 & 19 & 56 \\
& $(66.1)$ & $(33.9)$ & $(100)$ \\
\hline
\end{tabular}

Hasil uji Chi-Square program SPSS versi 18.0 dengan $\alpha=5 \%(0.05)$ diperoleh $p$ sebesar 0.026 sehingga nilai $p<0.05$, yang berarti $\mathrm{Ho}$ ditolak dan $\mathrm{H}_{\mathrm{a}}$ diterima, hal ini menunjukkan kelengkapan imunisasi dasar berperan dalam pertumbuhan anak usia 1-3 tahun di Posyandu Dewi Sawitri RW 07 Pucangan Kartasura.

Tabel 4.

Tabulasi Silang Kelengkapan Imunisasi dan Perkembangan

\begin{tabular}{ccccc}
\hline \multirow{2}{*}{ Imunisasi } & \multicolumn{3}{l}{ Perkembangan } \\
\cline { 2 - 5 } & Sesuai & $\begin{array}{c}\text { Tdk } \\
\text { sesuai }\end{array}$ & Total & $p$ \\
\hline Lengkap & 37 & 3 & 40 & 0.039 \\
& $(92.5)$ & $(7.5)$ & $(100)$ & \\
Tidak & 9 & 7 & 16 & \\
lengkap & $(56.3)$ & $(43.7)$ & $(100)$ & \\
\hline Total & 46 & 10 & 56 & \\
& $(82.1)$ & $(17.9)$ & $(100)$ & \\
\hline & & & &
\end{tabular}

Hasil uji Chi-Square program SPSS versi 18.0 dengan $\alpha=5 \%(0.05)$ diperoleh $p$ sebesar 0.001 sehingga nilai $p<0.05$, yang berarti Ho ditolak dan $\mathrm{H}_{\mathrm{a}}$ diterima, hal ini menunjukkan kelengkapan imunisasi dasar memiliki peran secara signifikan dalam perkembangan anak usia 1-3 tahun di Posyandu Dewi Sawitri RW 07 Pucangan Kartasura.

\section{PEMBAHASAN}

Berdasarkan hasil penelitian pada anak usia todler di Posyandu Dewi Sawitri Pucangan Kartasura menunjukkan jumlah responden yang mendapatkan imunisasi lengkap adalah 40 anak (71.4\%) dan responden dengan pemberian imunisasi tidak lengkap berjumlah 16 anak (28.6\%). Imunisasi yang diwajibkan pada anak meliputi BCG, Hepatitis B, DPT, Polio, dan Campak (Ridha, 2014). Imunisasi sangat diperlukan untuk memberikan kekebalan tubuh kepada bayi dan anak dengan maksud menurunkan angka kematian dan kesakitan (mortalitas 
dan morbiditas) serta mencegah/menghindari terjadinya akibat buruk lebih lanjut terhadap sekelompok penyakit (Riyadi, 2016). Di Posyandu Dewi Sawitri sebagian besar anak sudah mendapatkan imunisasi lengkap dan sesuai jadwal, hal ini menunjukkan sebagian besar masyarakat Pucangan Kartasura sudah memiliki kesadaran akan pentingnya imunisasi bagi anak. Pemberian imunisasi secara lengkap dan sesuai jadwal sangat penting karena merupakan investasi kesehatan masa depan dimana merupakan salah satu upaya pencegahan penyakit dan juga akan menghindarkan anak dari penyakit infeksi yang berbahaya (Chomaria, 2015).

Anak juga perlu dilakukan pemantauan pertumbuhan fisik untuk menentukan apakah pertumbuhan fisik seorang anak berjalan normal atau tidak, baik dilihat dari segi medis maupun statistik (Soetjiningsih dan Ranuh, 2014). Salah satu parameter pemantauan pertumbuhan fisik adalah dari hasil penimbangan berat badan. Pada masa bayi-balita, berat badan digunakan untuk mengetahui pertumbuhan fisik. Tujuan pemantauan pertumbuhan berat badan adalah untuk menilai hasil peningkatan atau penurunan semua jaringan yang ada pada tubuh (Yuniarti, 2015).

Berdasarkan hasil penelitian pada anak di Posyandu Dewi Sawitri, responden yang memiliki pertumbuhan optimal sebanyak 37 anak $(66.1 \%)$ dan pertumbuhan tidak optimal sebanyak 19 anak (33.9\%). Dari hasil tersebut menunjukkan sebagian besar anak memiliki pertumbuhan yang optimal. Selain pertumbuhan fisik, seiring dengan bertambahnya usia anak, maka anak akan mengalami perkembangan yaitu bertambahnya kemampuan (skill/ketrampilan) dalam struktur dan fungsi tubuh sebagai hasil dari proses pematangan (Soetjiningsih dan Ranuh, 2014). Berdasarkan hasil penelitian di Posyandu Dewi Sawitri Pucangan Kartasura, responden yang memiliki perkembangan sesuai sebanyak 46 anak (82.1\%) dan tidak sesuai sebanyak 10 anak (17.9\%). Hal ini menunjukkan anak yang memiliki perkembangan sesuai lebih banyak dibandingkan anak yang perkembangannya tidak sesuai.

Selama masa tumbuh kembang, perkembangan anak merupakan proses yang sangat penting. Perkembangan sangat berkaitan dengan pematangan fungsi organ tubuh (Ridha, 2014). Perkembangan memiliki pola yang teratur, akan tetapi kecepatan perkembangan setiap anak tidak selalu sama (Sulistyawati, 2014). Untuk itu anak perlu didorong supaya memiliki perkembangan yang optimal terutama pada usia $1-3$ tahun yang merupakan periode emas (golden period). Pertumbuhan anak yang optimal dan perkembangan yang sesuai dengan usianya merupakan hasil interaksi dari beberapa faktor yang mempengaruhi tumbuh kembang anak. Faktor lingkungan yang baik akan menunjang tercapainya tumbuh kembang anak yang baik (Soetjiningsih dan Ranuh, 2014). Demikian pula halnya yang terjadi pada anak di Posyandu Dewi Sawitri, pada anak yang memiliki pertumbuhan optimal dan perkembangan yang sesuai dimungkinkan karena dalam masa tumbuh kembangnya anak telah terpapar dengan lingkungan yang mendukung tumbuh kembang.

Hasil uji korelasi antara kelengkapan imunisasi dasar dengan pertumbuhan diperoleh $p$ value sebesar 0.026 ( $p<0.05)$, hal ini menunjukkan kelengkapan imunisasi dasar berperan dalam pertumbuhan anak usia $1-3$ tahun 
di Posyandu Dewi Sawitri Pucangan Kartasura. Dari 56 anak, yang pemberian imunisasi dasarnya tidak lengkap dan pertumbuhannya optimal sebanyak 7 anak (43.7\%) sedangkan anak yang pemberian imunisasi dasarnya tidak lengkap dan pertumbuhannya tidak optimal sebanyak 9 anak (56.3\%), dari hasil tersebut menunjukkan responden yang imunisasinya tidak lengkap lebih banyak yang pertumbuhannya tidak optimal. Demikian pula sebaliknya, anak yang pemberian imunisasi dasarnya lengkap dan pertumbuhannya optimal sebanyak 30 anak (75\%) sedangkan anak yang pemberian imunisasi dasarnya lengkap dan pertumbuhannya tidak optimal sebanyak 10 anak (25\%). Dari hasil tersebut menunjukkan responden yang imunisasi dasarnya lengkap lebih banyak yang pertumbuhannya optimal.

Salah satu faktor yang mempengaruhi pertumbuhan anak adalah kerentanan terhadap penyakit. Balita sangat rentan terhadap penyakit sehingga angka kematian balita juga tinggi terutama kematian bayi (Soetjiningsih dan Ranuh, 2014). Ketika anak sakit maka energi anak terserap untuk pemulihan dari kondisi sakit dan hal ini dapat menghambat pertumbuhan anak. Seperti hasil penelitian yang dilakukan oleh Kusminarti (2009), mengenai faktor - faktor yang berhubungan dengan pertumbuhan balita menunjukkan bahwa penyakit infeksi berhubungan secara signifikan dengan pertumbuhan balita $(p=0.003)$. Demikian pula penelitian yang dilakukan oleh Dewi dan Adhi (2016), menunjukkan bahwa faktor dominan yang mempengaruhi kejadian stunting di wilayah kerja Puskesmas Nusa Penida III adalah konsumsi seng $(\mathrm{OR}=9.94)$ dan riwayat penyakit infeksi (OR=5.41).

Untuk mencegah penyakit infeksi pada anak maka anak memerlukan perawatan kesehatan yang teratur yang tidak saja dilakukan ketika anak sakit, diantaranya pemeliharaan kesehatan, imunisasi, deteksi dini tumbuh kembang. Imunisasi sangat diperlukan karena dengan imunisasi terhadap berbagai penyakit maka anak akan terhindar dari penyakit infeksi (Soetjiningsih dan Ranuh, 2014). Demikian pula menurut Chomaria (2015), menyebutkan bahwa imunisasi merupakan salah satu upaya pencegahan penyakit. Imunisasi akan menghindarkan anak dari penyakit infeksi yang berbahaya sehingga selama masa tumbuh kembang, anak dalam kondisi sehat yang akan mendukung percepatan pertumbuhan anak.

Hasil penelitian menunjukkan bahwa kelengkapan imunisasi dasar berperan dalam pertumbuhan anak juga sesuai dengan hasil penelitian sebelumnya yang dilakukan oleh Hikmah, Riyantini dan Wahyuni (2016). Dari hasil penelitian disimpulkan bahwa ada hubungan antara kelengkapan imunisasi dasar dengan pertumbuhan anak $(p=0.000)$.

Pada penelitian ini juga didapatkan ada 7 anak yang tidak lengkap imunisasinya tapi pertumbuhannya optimal. Hal ini dimungkinkan karena adanya faktor lain yang mempengaruhi pertumbuhan diantaranya gizi, dimana anak yang memperoleh makanan yang cukup dan bergizi maka pertumbuhan fisik anak akan berlangsung dengan baik. Demikian juga apabila pada masa bayi memperoleh ASI eksklusif sampai umur 6 bulan serta pemberian ASI diteruskan sampai umur 2 tahun atau lebih akan berdampak positif pada pertumbuhan anak.

Pada korelasi antara kelengkapan imunisasi dasar dengan perkembangan anak, hasil uji ChiSquare program SPSS versi 18.0 dengan $\alpha=5 \%(0.05)$ diperoleh $p$ - 
value sebesar $0.001(p<0.05)$, hal ini menunjukkan kelengkapan imunisasi dasar berperan dalam perkembangan anak usia 1-3 tahun di Posyandu Dewi Sawitri Pucangan Kartasura.

Hasil penelitian pada 56 anak, yang pemberian imunisasi dasarnya tidak lengkap dan perkembangannya sesuai sebanyak 9 anak (56.3\%) sementara anak yang pemberian imunisasi dasarnya tidak lengkap dan perkembangannya tidak sesuai sebanyak 7 anak (43.7\%), sedangkan yang pemberian imunisasi dasarnya lengkap dan perkembangannya sesuai sebanyak 37 anak (92.5\%), sementara pemberaian imunisasi dasarnya lengkap dan mengalami perkembangan tidak sesuai berjumlah 3 anak (7.5\%). Dari hasil tersebut menunjukkan sebagian besar anak yang memperoleh imunisasi dasar lengkap memiliki perkembangan yang sesuai.

Perkembangan merupakan bertambahnya kemampuan (skill/ketrampilan) anak yang mencakup aspek kognitif, motorik, bahasa dan komunikasi, personal sosial dan emosional, serta moral dan spiritual (Yuniarti, 2015).

Setiap anak memiliki tugas perkembangan yang harus dicapai sesuai dengan usianya. Anak akan bisa melakukan tugas perkembangannya dengan baik apabila anak dalam kondisi sehat, sehingga anak perlu dihindarkan dari berbagai penyakit infeksi. Imunisasi merupakan suatu cara untuk meningkatkan kekebalan seseorang secara aktif terhadap suatu antigen, sehingga apabila kelak ia terpajan pada antigen yang serupa, tidak terjadi penyakit. (Kumalasari, 2015). Sehingga anak yang mendapatkan imunisasi lengkap akan memiliki kekebalan tubuh yang kuat dan akan menjadi anak yang sehat, dimana kondisi anak yang sehat akan mendukung perkembangan anak yang optimal. Demikian juga pada anak di Posyandu Dewi Sawitri, sebagian besar anak sudah memperoleh imunisasi dasar lengkap yaitu $71.4 \%$ dan perkembangan anak yang sesuai dengan usianya $82.1 \%$.

Jumlah anak yang memiliki perkembangan sesuai lebih banyak melebihi anak yang memperoleh imunisasi lengkap, hal ini dimungkinkan karena untuk mendukung perkembangan anak, selain dengan kondisi sehat juga dipengaruhi oleh faktor lain seperti pola pengasuhan orang tua dan stimulasi dari lingkungan yang merupakan hal yang penting untuk perkembangan anak, serta adanya faktor lain yang tidak dibahas dalam penelitian ini.

Hasil penelitian ini sesuai dengan penelitian yang dilakukan oleh Hikmah, Riyantini dan Wahyuni (2016), yang berjudul hubungan kelengkapan imunisasi dasar dengan tumbuh kembang toddler di Posyandu Bunga Padi Kota Tangerang diperoleh data sebanyak $85 \%$ balita diberikan imunisasi dan sebanyak $15 \%$ balita tidak diberikan imunisasi. Dari hasil penelitian disimpulkan bahwa ada hubungan antara kelengkapan imunisasi dasar dengan pertumbuhan anak $(p=0.000)$ dan ada hubungan antara kelengkapan imunisasi dasar dengan perkembangan anak $(p=0.000)$. Kerentanan terhadap penyakit dapat dikurangi dengan memberikan imunisasi secara rutin dengan begitu akan memberikan efek positif pada anak terutama pada pertumbuhan dan perkembangannya. Hasil penelitian yang dilakukan oleh Kaunang, Rompas dan Bataha (2016), juga menunjukkan terdapat hubungan pemberian imunisasi dasar dengan pertumbuhan dan perkembangan bayi ( $p$ value $=0.000)$.

Demikian pula dari penelitian ini menunjukkan kelengkapan 
imunisasi dasar berperan dalam pertumbuhan dan perkembangan anak usia 1-3 tahun di Posyandu Dewi Sawitri Pucangan Kartasura.

\section{KESIMPULAN}

1. Kelengkapan imunisasi dasar yang diperoleh anak sebagian besar lengkap yaitu sebanyak 40 anak $(71.4 \%)$.

2. Pertumbuhan anak lebih banyak pada pertumbuhan optimal yaitu 37 anak $(66.1 \%)$.

3. Perkembangan anak lebih banyak pada perkembangan yang sesuai yaitu 46 anak (82.1\%).

4. Hasil uji Chi-Square program SPSS versi 18.0 dengan $\alpha=5 \%$ (0.05) dari peran kelengkapan imunisasi dasar dalam pertumbuhan diperoleh $p$ sebesar $0.026(p<0.05)$ yang berarti imunisasi dasar berperan dalam pertumbuhan anak.

5. Hasil uji Chi-Square program SPSS versi 18.0 dengan $\alpha=5 \%$ (0.05) dari peran kelengkapan imunisasi dasar dalam perkembangan diperoleh $p$ sebesar $0.001 \quad(p<0.05)$ yang berarti imunisasi dasar berperan dalam perkembangan anak.

\section{SARAN}

1. Orang tua yang memiliki anak usia bayi agar mengimunisasikan anaknya secara lengkap minimal untuk imunisasi dasar (BCG, Hepatitis, DPT, Polio, dan Campak).

2. Kader Posyandu diharapkan lebih meningkatkan peran sertanya dalam memotivasi ibu supaya mau membawa anaknya untuk dilakukan imunisasi tepat waktu.

3. Petugas Puskesmas hendaknya semakin meningkatkan perannya dalam meningkatkan pengetahuan masyarakat mengenai pentingnya imunisasi pada anak.

\section{DAFTAR PUSTAKA}

Chomaria, N. 2015. Tumbuh Kembang Anak Usia 0-5 Tahun. Cinta, Surakarta.

Dewi, I.A.K.C dan K.T. Adhi. 2016. "Pengaruh Konsumsi Protein dan Seng Serta Riwayat Penyakit Infeksi Terhadap Kejadian Stunting pada Anak Balita Umur 24 - 59 Bulan di Wilayah Kerja Puskesmas Nusa Penida III." Arc. Com. Health. Vol. 3 No.1. Fakultas Kedokteran Universitas Udayana. Bali. Diakses tanggal 9 Januari 2018.

Dinkes. 2013. Pusat Data dan Informasi Kementrian Kesehatan RI. Jakarta. www.Depkes.go.id. Diakses Pada Tanggal 5 Oktober 2017.

Hikmah, Y., Riyantini dan Y. Wahyuni. 2016. "Hubungan Kelengkapan Imunisasi Dasar Dengan Tumbu Kembang Toddler Di Posyandu Bunga Padi Kota Tangerang", JKFT. $2 . \quad$ Universitas Muhammadiyah, Tangerang. Diakses pada tanggal 12 September 2017.

Kaunang, M.C., S. Rompas, dan Y. Bataha. 2016. "Hubungan Pemberian Imunisasi Dasar Lengkap Dengan Tumbuh Kembang pada Bayi (0-1 tahun) di Puskesmas Kembes Kecamatan Tombulu Kabupaten Minahasa". Ejournal Keperawatan.1. Prodi IImu Keperawatan Fakultas Kedokteran. Minahasa. Diakses 9 Januari 2018.

Kementrian Kesehatan RI. 2018. Hasil Pemantauan Status Gizi (PSG) tahun 2017. http.//www.kesmas. kemkes. Go.id/assets/upload/dir..BukuSaku-Nasional-PSG 2017975.pdf. Diakses tanggal 10 Januari 2018. 
Kumalasari, I. 2015. Panduan Praktik Laboratorium dan Klinik Perawatan Antenatal, Intranatal, Postnatal, Bayi Baru Lahir dan Kontrasepsi. Salemba Medika, Jakarta Selatan.

Kusminarti, D.E. 2009. Faktor Faktor yang Berhubungan Dengan Pertumbuhan balita usia 2-4 tahun di kelurahan Salaman Mloyo Kecamatan Semarang Barat kota Semarang. Skripsi. Universitas Negeri Semarang.

Ridha, H.N. 2014. Buku Ajar Keperawatan Anak. Pustaka belajar, Yogyakarta.

Riyadi, A.L.S. 2016. IImu Kesehatan Masyarakat. CV. Andi Offset, Yogyakarta.

Soetjiningsih dan IG. N. Gde Ranuh. 2014. Tumbuh Kembang Anak. Edisi II. EGC, Jakarta
Sulistyawati, A. 2014. Deteksi Tumbuh Kembang Anak. Salemba Medika, Jakarta Selatan.

Suryani, E dan A. Badi'ah. 2017. Asuhan Keperawatan Anak Sehat dan Berkebutuhan Khusus. Pustaka Baru Proses, Yogyakarta.

Yuniarti, S. 2015. Asuhan Tumbuh Kembang Neonatus Bayi Balita Dan Anak Pra Sekolah. PT Refika Aditama, Bandung.

${ }^{1}$ Dosen Akper Panti Kosala

Surakarta

${ }^{2}$ Mahasiswa Akper Panti Kosala

Surakarta 
"KOSALA" JIK Vol. 6 No. 1 Mei 2018 